Trinity University

Digital Commons@ Trinity

English Faculty Research

English Department

Winter 2013

\title{
David Foster Wallace and Lovelessness
}

David Rando

TrinityUniversity, drando@trinity.edu

Follow this and additional works at: https://digitalcommons.trinity.edu/eng_faculty

Part of the English Language and Literature Commons

\section{Repository Citation}

Rando, D. (2013). David Foster Wallace and lovelessness. Twentieth-Century Literature, 59(4), 575-595. doi: 10.1215/ 0041462X-2013-1006

This Article is brought to you for free and open access by the English Department at Digital Commons @ Trinity. It has been accepted for inclusion in English Faculty Research by an authorized administrator of Digital Commons @ Trinity. For more information, please contact jcostanz@trinity.edu. 


\title{
David Foster Wallace and Lovelessness
}

\author{
David P. Rando
}

\section{I}

$t$ has become a critical axiom that in his fiction David Foster Wallace turns irony inside out in order to express genuine emotion. "Wallace conceives a treatment for contemporary American solipsism that is drenched in hip irony and negates the 'Other" (143), Petrus van Ewijk writes, while Paul Giles observes that Wallace "turns ... irony back against the postmodern condition itself," an "ironization of irony [that] leaves scope for tantalizing glimpses of authentic experience" (340). Similarly, Marshall Boswell argues, "hip irony is itself ironized in such a way that the opposite of hip irony - that is, gooey sentiment - can emerge as the work's indirectly intended mode" (17).

While there is much to encourage such views, including Wallace's own essays and interviews - indeed, hip irony and gooey sentiment are Wallace's own terms ("E" 63, Infinite 694) -insufficient attention has been paid to the lack of emotion structuring his fiction, especially given the ways Wallace's fiction is crucially invested in affectlessness, most memorably perhaps in the character of Infinite Jest's Hal Incandenza, whose "anhedonia" is described as "a kind of radical abstracting of everything, a hollowing out of stuff that used to have affective content" (693). Infinite Jest also ties this condition of affectlessness to an ironic aesthetic: "It's of some interest that the lively arts of the millennial U.S.A. treat anhedonia and internal emptiness as hip and cool"; they guide us "to fashion masks of ennui and jaded irony" (694), and eventually these masks get "stuck there." The myth about Wallace's fiction, which Wallace himself helped to originate and his critics often reproduce, is that his texts put on these ironic masks only to ironize them, and in doing so they reclaim a space for affect and sentiment. Critics have not sufficiently challenged Wallace's categories, however, and have too often reproduced his own thought patterns. ${ }^{1}$ They do not quite make clear how it is that the masks become 
unstuck, how irony can be ironized so that unironic sentiment can find expression without in fact compounding irony so that it goes, as it were, all the way down. For this reason, I argue it is time to reevaluate the place of affect in Wallace's fiction as well as to reconsider the critical readings that tend to privilege affect over affectlessness and sentiment over irony.

We might begin by questioning Wallace's opposition of irony and sentiment-or rather by observing how his own formulations challenge this opposition. It is true that in "E. Unibus Pluram," for example, irony seems to have become a generalized protective response against appearing naive or sentimental: "The new rebels might be artists willing to risk the yawn, the rolled eyes, the cool smile, the nudged ribs, the parody of the gifted ironists, the 'Oh how banal.' To risk accusations of sentimentality, melodrama" (81). Similarly, in Infinite Jest, we see that "Hal, who's empty but not dumb, theorizes privately that what passes for hip cynical transcendence of sentiment is really some kind of fear of being really human" (694-95). Such passages seem to oppose sentiment to irony. But we might also reflect on how, as Wallace represents it, this opposition seems to fall apart: rather than a mere turning away from naive emotion, irony can also be described as a product of emotion, specifically the emotions of anxiety or fear about emotional vulnerability itself, or even "a fear of being really human." To the extent that Wallace formulates irony as a product of anxiety or fear, there is indeed something rather melodramatic about irony itself that makes it impossible to separate it from sentiment. In other words, sentiment and melodrama cannot be constructed as binary alternatives to cool irony if the equally powerful emotions of anxiety and fear are preconditions for irony in the first instance. If cool irony is shot through with melodramatic emotion, however, the collapse of their opposition cuts in both directions: if irony cannot be separated from the emotion it wishes to escape, sincere emotion cannot emerge from an irony itself defined as an emotional response functioning to protect against the very feelings by which it was prompted. Though this conceptual collapse of the sentimentirony opposition has gone generally unrecognized by Wallace's critics, it nonetheless plays out on different levels of his fiction. What Wallace does best is to dramatize as vividly and with as much pathos as anybody before him the struggle and failure to differentiate gooey sentiment from the sentiment of irony. 
Contrary to the tendency to privilege apparently unironic moments of sentiment plucked from Wallace's texts, I want to step back and observe the larger patterns and structures that suggest instead a continuous struggle to overcome irony that ultimately fails. There is no better way to do this than by tracking one of Wallace's persistent preoccupations: the sentiment of love and love's absence. Indeed lovelessness may be the major concern of Wallace's work. Both Infinite Jest and its eponymous film revolve around the presence or absence of a mother's love. With the exception of Mario, the entire Incandenza family is disfigured by its members' failure to feel love or to express love. In The Pale King, Lane Dean, having impregnated Sheri Fisher, asks himself "why is he so sure that he doesn't love her? Why is one kind of love any different? What if he has no earthly idea what love is?" (43). In "Good Old Neon" from Oblivion and "Brief Interview \#20" from Brief Interviews with Hideous Men, characters have epiphanies about their own lovelessness, their inability to love or even to understand what love is.

Indeed, in the following it is primarily through these two stories that I examine Wallace's fiction's lack of emotion, especially its lovelessness on the levels of story and discourse. Considering the ways in which their ironic form can itself be viewed as a kind of lovelessness complicates the common view of affect's place in Wallace's fiction. While Wallace's characters often remain loveless because of their fear of emotional connection, these values are mirrored on the level of literary form as well, in narrative structures that constantly undercut unironic sentiment. Irony on the level of discourse is thus enmeshed with lovelessness on the level of story, as Wallace views both as anxious or fearful alternatives to the powerful feelings associated with sentimentality and melodrama. Recognizing in his work the importance, not of affect and love, but of affectlessness and lovelessness reveals that if Wallace's writing is itself affecting, it is not because it discovers an alchemical way of transmuting postmodern irony into golden sentiment, but because it so vividly stages the chemical covalence of love and fear. Contrary to dominant emotional triumphalist readings of Wallace, therefore, I will argue that the very failure of love to emerge and separate itself from irony constitutes the affective drama of Wallace's work. 


\section{Loveless characters}

The key coordinate for Wallace's representation of love and lovelessness is James Joyce. Like Wallace's, Joyce's world is peopled with characters unable to love: James Duffy, Little Chandler, Gabriel Conroy, and more. Perhaps Stephen Dedalus fits this loveless mold as well, as he rejects Cranly and his father, and feels haunted by the ghost of a mother who loved him but for whom he could not be moved to pray. Wallace's treatment of lovelessness is a Joycean legacy: the whole of Infinite Jest might be regarded as an elaborate and ironic gloss on Stephen Dedalus's meditation on "mother love" in Ulysses- " Amor matris, subjective and objective genitive, may be the only true thing in life" (9.842-43)—or on Cranly's view in A Portrait of the Artist as a Young Man that, "Whatever else is unsure in this stinking dunghill of a world a mother's love is not" (213), though Infinite Jest innovates on this theme by imagining the way in which a mother might literally love a child to death. Stephen Burn has noted that Infinite Jest "is stalked by the ghost of a tall alcoholic author named Jim" (20). Burn correctly estimates Joyce's importance to Wallace. In fact, as when "the ghostish figure that's been flickering in and out of sight around the room finally stays in one spot long enough for Gately to really check him out" (Infinite 829), Wallace's fiction crystallizes his relationship with Joyce at certain crucial moments of "a sort of epiphanyish visitation" (833).

One such set of moments occurs when Wallace rewrites the epiphany of lovelessness that concludes "The Dead." When Gabriel learns about Michael Furey's sacrifice for Gabriel's own wife, his eyes fill with "generous tears. He had never felt like that himself towards any woman but he knew that such feeling must be love" (194). "Brief Interview \#20" and "Good Old Neon" contain nearly identical moments. "Brief Interview \#20," conducted on "12-96" and thus sharing a Christmas/New Year's setting with Joyce's story, likely set during the Feast of Epiphany in early January, builds toward such a moment, though with considerably more self-consciousness about doing so: "I realized I had never loved anyone. Isn't that trite? Like a canned line?" (313). This realization is evoked by a story about abduction, rape, and near murder told by a woman the interviewee has picked up for a one-night stand (I will take a risk and call this interviewee a law student, since we know he is a graduate student [289], alludes to his friend's torts study group [283], and uses legalistic rhetoric). Like Gabriel, the unnamed speaker "focused very intently on her story" 
(310) and "began to cry at the anecdote's climax" (316). Similarly, the speaker who considers himself a fraud in "Good Old Neon" says, "the idea struck me that maybe the real root of my problem was not fraudulence but a basic inability to really love" (165).

The horror of lovelessness is a consistent thread in Wallace's writing. Reviewing Toward the End of Time, for instance, Wallace criticizes John Updike's male "emotional solipsists": "Though usually family men, they never really love anybody — and, though always heterosexual to the point of satyriasis, they especially don't love women" ("Certainly" 53). Wallace contrasts Updike's preoccupations with a set of fears whose difference Wallace describes as generational, but which nonetheless are also especially his own: "today's subforties have very different horrors, prominent among which are anomie and solipsism and a peculiarly American loneliness: the prospect of dying without even once having loved something more than yourself" (54). Although this horror of lovelessness could apply equally to both men and women, and critics have surely privileged questions of maternal love in his texts, as the title of Brief Interviews suggests, Wallace's work is also peculiarly invested in diagnosing male lovelessness as a form of hideousness.

By at least the 1980s, deriving insight from feminist theory, critics had similarly begun to attribute hideous qualities to Gabriel Conroy, revising what Vincent Cheng has called the hitherto "Authorized Version" of Gabriel, which understood him as a fundamentally decent but flawed man "who nevertheless in the end arrives at a deeply moving and universal, humanizing epiphany" (129). In contrast to this view, for instance, Cheng sees Gabriel as "a potentially oppressive patriarch in symbolic collaboration with the ruling masters of the English colonial empire" (135). Ruth Bauerle focuses on Gabriel's lovelessness when she suggests that a possible outcome of Gretta's story might be a journey westward that "could free Gretta from Gabriel's unfeeling lust, as it could free Gabriel to experience deep love" (118). In a spirit similar to critical revisions such as these, Wallace rewrites "The Dead" so that what is most hideous about such characters is precisely their masculine lovelessness. Wallace suggests that lovelessness is hideous by associating its revelation with fear and horror, terms that suggest Aristotelian tragic catharsis, as when the law student accounts for his epiphany: "I began in the dark of our room to feel terrible sadness and fear. I felt as though there had been far more genuine emo- 
tion in and connection in that anti-rape she suffered than in any of the so-called lovemaking I spent my time pursuing" (312, emphasis added).

The revelation of lovelessness in "Brief Interview \#20" and "The Dead" results in each case from four primary conditions. First, there is a mechanism in each story in which the revelation of lovelessness is made through the man's homosocial preoccupations with and reflections on other men in the woman's narrative, which thus mediates between them. In "Brief Interview \#20" and "The Dead" the men see themselves in relation to past men who have also been involved with the respective woman: for Gabriel, Michael Furey, and for the law student, the rapist/murderer. In Gabriel's case the homosocial relation with Michael Furey is one of perceived contrast between the passionless analyst and the self-sacrificing lover. By measuring his position within the theoretical love triangle he and Michael Furey form with Gretta, Gabriel is forced to recognize his own lovelessness. The structure is much the same in "Brief Interview \#20," but rather than perceiving contrast with the other man, the law student finds a horrifying similarity to the loveless rapist who objectifies and murders women as a substitute for love relationships that would be unthinkably engulfing. Consistent with Eve Sedgwick's model of homosociality, the women are treated as conduits through which Gabriel and the law student can puzzle out their relationships to the men who preceded them. We can see, however, that these women are hardly passive conduits, but rather powerful conductors (or perhaps orchestrators) who, as storytellers, act as conduits in the root sense: to "bring together."

Although "Good Old Neon" does not conform to the established pattern in which a male character arrives at a sudden understanding of his own lovelessness by listening to a story told by a woman about her experience with another man, there is still a homosocial element at work in this story. In a Cheers rerun, Lilith's ${ }^{3}$ offhand comment- "If I have one more yuppie come in and start whining to me about how he can't love, I'm going to throw up" (168) - to Frasier, the other man in this televisual triangle, devastates the narrator. His own agonizing and apparently irresolvable condition is represented as a joke, the loveless yuppie reduced to a stock type millions of Americans will immediately find funny: "I was nothing but just another fast-track yuppie who couldn't love, and ... I found the banality of this unendurable" (173). Like the law student of "Brief Interview \#20," he "recognized what a cliché and melodramatic 
type of complaint the inability-to-love concept was" (168), and in a "flash," "it more or less destroyed me, that's the only way I can describe it" (169).

The second condition for the revelation of lovelessness is that the man tends to infantilize the woman, and generally views women typologically. In "The Dead" and "Brief Interview \#20," the male characters' infantilization of women is the base condition that prompts the discovery of their own lovelessness. Noting the way Gabriel accounts for their late arrival by telling his aunts that Gretta "takes three mortal hours to dress herself" ("Dead" 153), Cheng argues that his "seemingly good-humored comment suggests ... an essentializing of the female in the form of infantilization" (135). Similarly, the law student admits that it is "exceedingly hard to take [women of the "Cruncher genus"] seriously" (289). Such infantilization is related to a persistent "typological" imagination of women, as in the law student's classification of women into various genera (289-90). While Gabriel Conroy appears to classify women less consciously, he too views them typologically. His aunts are "two ignorant old women" (167); he treats Gretta (whom Gabriel's mother uncomfortably classed as a "country cute" [162]) and Molly Ivors ("thoughttormented" [177]) quite differently according to how he perceives their geographical origins, educations, and occupations. In fact, the interviewer of "Brief Interview \#20" seems to be the equivalent "type" for Molly Ivors in Wallace's story, a politically informed woman whose response to his story the narrator constantly tries to gauge and co-opt. Throughout, the law student attempts to preempt the feminist interpretation to which he imagines the interviewer will subject his story by formulating it himself. This mechanism sets up the story's vulgar ending, so different from the lyrical conclusion of "The Dead." Betraying his own inability to control the interpretation of his narrative, he finally tries to silence the woman: "Judge me, you chilly cunt.You dyke, you bitch, cooze, cunt, slut, gash. Happy now?” (318).

The third crucial part of this pattern is that the male infantilization of women is surprisingly defied by each woman's powerful act of storytelling. Indeed, at the root of infantilizing typologies of women in these stories may be the issue of speech and speechlessness ("infant" derives from "unable to speak"). The law student views his object as only a onenight stand in part because of "the grim unimaginability of having to talk with a New Age brigadier for more than one night" (289). Gabriel feels 
most favorably toward Gretta when she is silent and "listening to distant music" (182); when he aestheticizes her in that posture, painting her in his mind as Distant Music, he begins to lust for her. As Margot Norris writes, "Gabriel's story [is] told in what we might call the audible or 'loud' text, with a largely silent but disruptive feminist countertext" (98). What eventually stun Gabriel and the law student into their respective epiphanies are the anecdotes that Gretta and the unnamed woman unexpectedly tell. Shockingly, the "infants" speak. When the women of Joyce's and Wallace's stories speak, it is with devastating power that exposes the male characters' understandings of the histories of their lovers as false, but also cuts through their own basic self-conceptions, forcing each to acknowledge with shock that he has been living a life of self-deception.

In these narratives it is crucial that the form of the woman's story is indeed an "anecdote," the word with which Wallace's student continually classifies the woman's story. Here the anecdote emerges as a narrative form inimical to cliché and resistant to the stale conventions of melodrama. These anecdotes work against the buffer that forms when powerful feelings, through repetition, have become clichés. When the law student coaches the interviewer about how to receive the anecdote, he issues metafictional instructions to readers as well: "I'm well aware that what she is about to describe is nothing but a variant of the stale old Love Will Conquer All bromide but for the moment bracket whatever contempt you might feel and try to see the more concrete ramifications" (300). Gretta's power as a storyteller issues from the way her anecdote unexpectedly reaches past her husband's multiform defenses (at first Gabriel responds "coldly" (190) and with "irony" (191) and "sarcasm"). The anecdotal form helps to bracket ironic reactions to cliché, to reinstall the epiphanic where for too long there has only been the melodramatic. The anecdote can thus be defined as a potential antidote to the listener's rote contempt for cliché.

Finally, in each story, the epiphany of lovelessness is not only prompted by an infantilized woman and her anecdote about, or comment to, another man, but is always also closely linked to death. Gabriel's epiphany concludes with his famous vision of death: "His soul had approached that region where dwell the vast hosts of the dead" (194). The law student begins by claiming,"And yet I did not fall in love with her until she had related the story of the unbelievably horrifying incident in which she was brutally accosted and held captive and nearly killed" (287). Gretta 
describes a young man who died for her while the law student's lover details how she nearly died at the hands of her rapist. These anecdotes affect the men in part from their proximity to death, suggesting that death and lovelessness are closely associated. Consistent with Infinite Jest, "Brief Interview \#20" links death and women.

With respect to "The Dead" and "Brief Interview \#20," the generic innovation of "Good Old Neon" is to present the epiphany of lovelessness as exactly congruent to death. Instead of being merely proximate to the revelation of lovelessness, in "Good Old Neon" death becomes the mode of revelation itself, "more like the sudden internal flash or whatever of epiphany or insight" (167), the "flash like neon" (179n) from which the story takes its title. In this much more extreme equation, because the speaker is frustratingly unable to shepherd his experiences around the obstacles of cliché and melodrama (176), he resorts to suicide as a mode of communication. "Good Old Neon" proposes death as a solution for language's great inarticulateness, its inability to communicate life's most meaningful experiences. Wallace figures this dilemma by imagining that inside each person is "this enormous room full of what seems like everything in the whole universe" (178), and yet all that can be seen or communicated of oneself has to be squeezed through the old-fashioned keyhole in the door, the figure for language. Wallace's speaker imagines his death will fling open the door:

Think for a second - what if all the infinitely dense and shifting worlds of stuff inside you every moment of your life turned out now to be somehow fully open and expressible afterward, after what you think of as you has died, because what if afterward now each moment itself is an infinite sea or span or passage of time in which to express it or convey it, and you don't even need any organized English, you can as they say open the door and be in anyone else's room in all your own multiform forms and ideas and facets?

Wallace here reworks Clarissa's idea in Mrs. Dalloway that, for Septimus Smith, "death was an attempt to communicate" (180), and his image of an "infinite sea" and the notion that "you don't even need any organized English" also evokes Freud's pre-and post-linguistic "oceanic feeling," a sense of all-embracing inclusiveness of which the ego is merely a "shrunken residue" (15), and language the ego's inadequate keyhole. The imagery 
may also suggest such associations of the ocean with both maternal lifegiving and death-bringing as occur in Ulysses; for Buck Mulligan the sea is both "our great sweet mother" (1.80) and "our mighty mother" (1.85) in which a man has recently drowned.

It would be a mistake, however, to think that Wallace merely endorses the concept of suicide as communication or holds it up as the ultimate anecdotal shock. For him, the extremity of thinking about suicide as a form of communication transfers attention from the narrator to the listener. "Good Old Neon" concludes with the speaker envisioning a former classmate, "David Wallace," learning about the narrator's suicide and attempting "to imagine what all must have happened" (180). The story ends not by affirming suicide as the sole means of real communication but rather by enjoining listeners to take up their own part in a now two-way effort to shuttle experience past cliché. ${ }^{5}$ The listener's part in this effort is truly to listen and to quiet the part of the mind that dismisses experience as cliché, "the realer, more enduring and sentimental part of him commanding that other part to be silent" (181). The suicide in "Good Old Neon" is thus another means by which to make the revelation of lovelessness new, to command a certain kind of attention from listeners, and to compel them to admit the powerful experiences of others past their filters for cliché and melodrama.

\section{Heartless structures}

Just as lovelessness characterizes the world of "Brief Interview \#20," so is it reproduced in the story's structure. While the story seems to offer itself as a space where affect untainted by irony emerges through the law student's revelation of lovelessness, the ironic structures of the story caution against such a reading. It is more accurate to say that this is a story about not having a heart (understood as an emblem for affect) that is itself without a heart (understood as a center), because it lacks a stable core to ground its own affective meaning. On the one hand, this argument relies on the coincidence of two different kinds of hearts- heart as affective metaphor and heart as structural center-so in some sense the reading that follows attempts to make "mere coincidence respectable," as in Thomas Pynchon's The Crying of Lot 49, when two forms of entropy, thermodynamic and informational, happen to look alike as equations and are imaginatively united in Maxwell's Demon (87). On the other hand, I 
have been arguing all along that the equation of these two kinds of hearts is characteristic of Wallace's texts, those Maxwell's Demons of the heart: for Wallace, narrative hearts and sentimental hearts should enable and reinforce one another. ${ }^{6}$ This correlation of hearts also gets reproduced in Wallace criticism as when, for instance, Boswell describes the "mysterious act of empathy that lies at the center" of "Brief Interview \#20" as "the story's true heart" (197). In this formulation, we see how in Wallace's texts affective and structural hearts would beat as one. What remains, then, is to show the mechanisms through which, contrary to authorial and critical hopes about loving and faithful structural and affective centers, these two hearts beat as none.

The story builds its heartless structure on the gradually revealed parallel between the law student and the rapist. Rather than functioning as the orienting core of the text, this identity produces vertiginous irony, as the law student both invites recognition of and deflects attention from this identity. Further, the law student sets a trap for his listener and readers in the very place where the heart of this story should be. Where the story's affective heart would be, there is a central vacancy, ensnaring readers who think they have found a privileged locus of emotional meaning. Moreover, one might argue sensibly that the law student, and thus his entire tale, is already in the grip of an ironic trap set by the woman, of which he is completely unaware. The anecdotal nature of the woman's story seems both to provide and deny the story a heart. The cardiac kernel pumping blood to all extremities of the story, the anecdote turns out to be a faithless heart, traveling from one interpretive structure to the next and adhering to several mutually exclusive interpretations simultaneously, which even, as I will show, unexpectedly and ironically becomes the very condition for love in the story.

"Brief Interview \#20" allows readers to piece together a parallel identity between the law student and the rapist so that they seem distinguished from one another more by degree of predation and violence than by kind or type of "hideous man." This process begins immediately in the interview transcript when in response to the first question the law student says, "she related an anecdote about hitchhiking and once being picked up by what turned out to be a psychotic serial sex offender" (287), while, in response to the third question, the law student admits that his seduction of the woman at the community festival "was a pickup, plain and simple" (288). The kindred signifiers "pickup" and "picked up" sug- 
gest that the law student and murderous rapist are oriented toward the woman in a similar way, seeing her as both object and objective. The law student, in legalistic idiom claims "nolo to the charge that I spotted her on the blanket at the concert and sauntered carnivorously over with an overtly one-night objective" (289).

"Pickup," "objective," and "carnivorous" all suggest that "Brief Interview \#20" is less a story of a would-be one-night stand during which an anecdote of rape and near murder is related than a story that itself repeats or reenacts the anecdote with a difference. This difference is emblematized by the law student's interrupted account of his friend's view of the woman at the festival: "Tad said she was like some kind of smooth blank perfect piece of pseudo-art you want to buy so you can take it home and sm-" (290). The suspension, mid-word, of "smash" mimics the equivalent trajectories of pickup and abduction and the relative, but not exactly entire, aversion of violence in the pickup.

This aestheticization and objectification of women is also evident in "The Dead," which similarly approaches but skirts violence. As we have seen, Gabriel Conroy imagines Gretta transfigured into a perfect piece of pseudo-art, Distant Music, and then into an object of lustful desire. Critics have noted the resemblances between Gabriel's aestheticization of Gretta and the Duke of Ferrara's literal reduction of his last wife to art in Robert Browning's "My Last Duchess." Norris, for instance, finds in Joyce's story and Browning's poem a common "appreciation of female beauty that resents the life and living feeling of the subject, and therefore proceeds to murder the living woman in order that she might perdure as she is desired, as pure representation" (102). Bauerle suggests that what Joyce describes as Gabriel's urge to "crush her body against his, to overmaster her" (189)—resembles the impulse toward date or mate rape (118).

The law student refers to how psychopaths "do not see [their victims] as human beings at all but merely as objects of the psychopath's own needs and intentions" (301). Readers of "My Last Duchess" struggle to evaluate how much the Duke gives away deliberately or unwittingly; similarly, early in "Brief Interview \#20" it is difficult to gauge the extent to which the law student realizes the equivalencies between himself and the rapist, or how deliberate he is about suggesting them to the interviewer. Building a case about the law student's unconscious relation to the rapist and the anecdote he is retelling, the reader will eventually arrive at especially damning evidence-moments when the law student could just as 
well be describing himself as the rapist, as when he discusses "the terror that any conventional, soul-exposing connection with another human being will threaten him with engulfment and/or obliteration, in other words that he will become the victim" (303).

When the law student eventually shows his hand, we recognize that, like the Duke of Ferrara, he may have been in control of the implications of his narrative all along:

Nor is this of course all that substantially different from a man sizing up an attractive girl and approaching her and artfully deploying just the right rhetoric and pushing the right buttons to induce her to come home with him, never once saying anything or touching her in any way that isn't completely gentle and pleasurable and seemingly respectful, leading her gently and respectfully to his satin-sheeted bed and in the light of the moon making exquisitely attentive love to her and making her come over and over until she's quote begging for mercy and is totally under his emotional control and feels that she and he must be deeply and unseverably connected. (303-304)

The law student tries to anticipate at every turn the response of the woman who is questioning him and, by extension, the readers' response to the story. "I know I'm not telling you anything you haven't already decided you know" (304), he says, but "Do not think you are getting out of me things or admissions I'm unaware of" (305). You almost expect him, like the Duke of Ferrara, to whip out a bronze figure of Neptune taming a seahorse.

The law student certainly attempts to master the meaning of the woman's anecdote by centering it as the supposed heart of the story, but we should pause before being persuaded by one whose "candid openness is potentially a trap" (195), as Boswell puts it. Even the congruence between seduction and rape the law student patiently builds needs to be questioned and qualified, for everything in the story is calculated as a snare. Indeed, the story can be viewed as a trap within a trap. There are traps for readers set by the self-reflexive narrator, of course, but beyond his own otherwise acute awareness he may himself have fallen into a trap set by the woman's "artless" anecdote itself. Our first hint of this possibility comes in the initial pickup, during which the woman shows an "amused expression during the whole conversation that made it hard not to smile 
in return" (291). This amused expression may suggest that the woman perceives not only that the law student wants to pick her up for a onenight stand (through his artful artlessness about his own artfulness), but also that she can deploy a tactic here similar to that which she used effectively in her earlier abduction and rape. Perhaps she already recognizes the equivalencies that the law student will only later make to connect himself and the rapist. What once saved her life was the ability to create a soul connection with the rapist, and now she tells the very anecdote about this life-saving soul connection to in effect transform a predatory one-night stand into a love relationship, turning the tables on the law student until he "feels that she and he must be deeply and unseverably connected."

By emphasizing his interpretive power in relation to the anecdote, the law student tries to separate the woman from the power of her story. For him it becomes mere raw material for the male consciousness to transfigure into a refined epiphany. He sees the story of an objectified woman as itself an object, rather than as the complex performance that it is. Indeed, despite her apparent artlessness, this woman is remarkably able to draw men into emotional connection with her. To take the law student's word about her "fluffiness or daffiness or intellectual flaccidity or a somehow smug-seeming naiveté" (289), then, is both to accept his limitations as our own and to deny the woman's anecdote as a meaningful verbal performance even before it is experienced or interpreted as epiphanic by a man. Is everybody inside and outside of the story really meant to see its correspondences except for the very woman who twice is positioned as object and objective, and who, moreover, only chooses to tell the anecdote of the first experience during this second experience "in response to some sort of prompt or association" (287)? We must consider both that the woman has been the active force, telling a powerful story in just the right context, rhetorically intervening to make a loveless man connect to and love her as more than a silent object, and that the law student, despite his own proud self-reflexivity, may not finally understand her story, his own, or who has power in both.

"Brief Interview \#20" demonstrates the way in which the anecdote is less like the heart of a single larger story, and more like a peculiar transmitter that bonds for each listener at a different receptor. For the law student, the receptor is a love/fear binary common to Wallace's work. The "Good Old Neon" narrator, for instance, defines "two basic, fundamental orientations a person could have toward the world, (1) love and (2) fear, 
and ... they couldn't coexist" (164); the narrator's ex-girlfriend in "Here and There" says, "I think feeling like he loved somebody scared him" (171). And certainly, "Brief Interview \#20" can be read as a story about reversing this binary, a character overcoming the terror of connecting with another, shedding protective irony, and finally experiencing love: "She had all my attention. I'd fallen in love with her. I believed she could save me. I know how this sounds, trust me.... I knew she could. I knew I loved. End of story" (317-18).

However, to stop here and to regard the story as having converted fear to love, is to obey a No Trespassing sign staked by an author who has no authority over interpretative territory. Such a reading overprivileges Wallace's "E Unibus Pluram: Television and US Fiction" (along with his interviews) as a kind of manifesto and thus as an interpretive shortcut through his fiction. However, not only was this essay written before the publication of his best and most mature work, but it is insistently predictive and conditional rather than descriptive, as in, for instance, this much-cited passage: "The next real literary 'rebels' in this country might well emerge as some weird bunch of anti-rebels, born oglers who dare somehow to back away from ironic watching, who have the childish gall actually to endorse and instantiate single-entendre principles" (81). Evoking that essay, Burn writes, "The only way forward, for Wallace, is to effect a break with postmodern practice, and abandon protective irony and risk sincerity" (17). ${ }^{7}$ Boswell argues, "he employs cynicism-here figured as sophisticated self-reflexive irony-to recover a learned form of heartfelt naïveté, his work's ultimate mode and what the work 'really means,' a mode that Wallace equates with the 'really human"' (17).Despite what Wallace might call Boswell's "flexion of upraised fingers to signify tone quotes" (Brief 100), Boswell affirms rather than distances himself from Wallace's formulation, arguing that he "has found that way" (18). Nonetheless, as Wallace's phrase "might well emerge" indicates, his formulations are conditional. For too long, critics have seen the principles of Wallace's manifesto as already manifest in his fiction.

It is true that some critics have countered the prevailing view that Wallace turns irony against itself to represent sincere emotion. Mary Holland, for example, argues that, in spite of Wallace's stated intentions, his earnest characters in Infinite Jest are "still doomed, almost sadistically so, by an author who cannot overcome his own ironic ambivalence" (220). This argument productively questions authorial proclamation, but it re- 
sorts to speculation about the author's psychological predilections, locating ironic ambivalence in the author himself rather than trying to reckon with the qualities of fictional irony that make Wallace's own arguments against irony untenable. Critics like Charles Harris and Frank Cioffi argue not that sincere emotion emerges from irony but rather that irony continuously qualifies emotion, emphasizing Wallace's alienation effects rather than his affect effects. Infinite Jest, Cioffi writes, "uses alienation effects to create its quirky, highly performative world with which the reader empathizes but from which she must also withdraw" (162). ${ }^{8}$ Such readings usefully resist the dominant critical axiom, but finally they do so simply by reprioritizing the elements of the axiom rather than challenging the basic formula, emphasizing the ironic over the affective side of the equation. In such readings, the opposite of an emotional triumphalist is an ironical triumphalist.

My reading of "Brief Interview \#20" has tried to suggest that in Wallace's work irony and affect are not counterposed but rather thoroughly conflated. Affect is not merely undercut or estranged by irony; rather, irony is itself a response to the emotion of fear, a kind of affect, while ironic or loveless structures emerge as the condition for affect in the first instance. The emotional and terminal interpretation of the anecdote that the law student would like to enforce is thus only the beginning of its significance. Unmediated by any one particular context, the woman's anecdote continues to operate in virtually infinite possible contexts, within and outside of the narrative. An emotional connection is made in the story, but Wallace never demonstrates that love overcomes ironic mechanisms. Indeed, the connection is not achieved through any exchange of sincere sentiment, but rather through a highly complex rhetorical performance in which an anecdote is deployed and travels to different receptors for each participant. The anecdote connects the characters because it is malleable and thus potentially compatible with any number of potential frames; the story's heartless heart, it can become the center of any number of other stories yet remains faithful to none. It mediates between people, connecting them not just despite but also because of differences between its initial motivation and its variegated interpretations. The anecdote is precisely what joins together the law student and the woman, yet they surely do not understand her story in the same way. If their relationship is premised, each from the perspective of the other, on the "wrong" interpretation of the story, has Wallace ever backed away from ironic watching? 
"Brief Interview \#20" neither transcends irony nor arrives through extensive self-reflexive purgation at a final emotional terminus despite irony. In it, irony and unironic emotion exist intractably in precisely the same space; the affect of love emerges because of the lovelessness of irony. Further, emotion and sentiment never overcome or separate themselves from irony, despite what Wallace claims in essays and interviews, or what critics taking his lead have argued. To maintain that Wallace uses irony to overcome irony, creating an "Irony-free zone" (Infinite 369) into which sentiment can finally emerge, is to view Wallace's texts as teleological and, with respect to affect, terminal, to the extent that Wallace's "might well emerge" suggests a desired outcome and an end point. However, as "Brief Interview \#20" demonstrates, irony and affect are locked in an irresolvable relationship - irony is a response to affective stimuli while affect is predicated upon ironic structures - made more complicated by mutually reinforcing layers of loveless story and heartless discourse.

\section{The price of Wallace's apple}

Wallace's fictional irony is thus a form of lovelessness that cannot be made to love despite what critics or Wallace's own essays and interviews assert. If for Wallace irony is a protective response to fear-the fear of being open, sentimental, loving, human, and so on-then Gabriel Conroy, the law student, and the narrator of "Good Old Neon" are all figures for the very lovelessness of ironic fiction itself. Instead of using irony and fear finally to overcome themselves and thus restore love and unironic sentiment to fiction, Wallace demonstrates that love and fear are infinitely porous. This is why Wallace's fiction can be so affecting and yet not affective, if affective means unironically manifesting sentiment and emotion. The source of Wallace's attraction is not that he allows weary, irony-saturated audiences to finally step back from ironic watching and experience naive sentiment, but rather that he exposes irony as an integral part of the emotional circuit. Wallace is the writer who most vividly demonstrates not that his own army of lovers must continually be beaten by a pack of infinite jesters, or vice versa, but that the lovers and jesters cannot finally be separated out.

In Wallace's fiction, there is no return to a pre-ironic state, if ever there has been one. Although we have been forced to refer to the woman in "Brief Interview \#20" simply as "unnamed," and since we have already 
encountered a Lilith, let us here take another nominal risk and call her Eve. When the law student first sees Eve, "her weight was on one arm stiff-armed out behind her and the other hand held the apple-am I describing this right?" (313). In a devilish, even serpentine, metafictional gesture, Wallace at once signals his recasting of a prelapsarian archetype and asks readers to consider whether or not he's doing it "right," that is, as expected. One thing Wallace has altered, of course, is that this is "a supermarket apple with a small supermarket price sticker still affixed to it" (311). Like the law student, we watch "with a sort of detached amusement to see whether she would eat the price sticker without taking it off." The price of the biblical Eve's apple was Edenic innocence, but if this new Eve can eat the price sticker, perhaps she, like the story itself, can hope to erase the price of experience. This promise of the return to innocence is the very substrate we have been taught by Wallace and his critics to identify under his fiction. But nothing would be more ironic or experienced than knowingly to swallow the price tag of forbidden fruit. Accomplishing that would require a more innocent gesture; Wallace's Eve must eat the price sticker unconsciously, even as the narrator and readers look on with detached amusement. Yet the whole structural recasting of the loss of innocence is itself inescapably ironic. What fallen reader dare back away from ironic watching? Eve may be unconscious, but her sitting there as an Eve figure eating a supermarket apple makes her the embodiment of irony itself. As in all of Wallace's fiction, the question then becomes whether irony can be made to appear to unconsciously consume irony while readers consciously observe it and the author self-consciously looks on. Unfortunately, in this story, the only one who can tell us for sure, who can affirm that innocence (or unironic sentiment) really can emerge from experience (or ironic fear) is the law student. And now it is clear why he must speak the law's idiom, for the whole story hinges on his testimony, which appears sincere and yet ironically is inconclusive: "I can't for the life of me recall whether she ate the price sticker, nor what became of the apple at all, whether she discarded it or what" (314-15).

\section{Notes}

1. To add to the views cited above, for instance: Iannis Goerlandt claims that Infinite Jest, "explicitly functionalizes the abstract level of 'superstructure' ... of poetic texts to counter an ironic reading" (310); Catherine Nichols writes, "Wallace turns the carnivalesque against itself to reveal a literary vision that 
foregrounds the line between transgression for its own sake and the use of art for redemptive purposes" (3); Timothy Jacobs likens Infinite Jest to The Brothers Karamazov, described as a "'novel of belief,' belief in humanity's necessary ability to confront the darkest aspects of itself and redeem them through language" (269); Robert McLaughlin calls Wallace a "post-postmodernist" with "a desire to reconnect language to the social sphere or, to put it another way, to reenergize literature's social mission, its ability to intervene in the social world, to have an impact on actual people and the actual social institutions in which they live their lives" (54); and James Rother similarly historicizes Wallace as part of "a third generation ... whose quiet revolution in the realm of fictional technique has scrapped deadpan irony" (216). There are, of course, dissenting views and I discuss some of these below.

2. While Joyce seems consciously to battle cliché and melodrama in "The Dead,'Wallace writes in the aftermath of Joycean techniques of epiphany, which have themselves come to seem clichéd and melodramatic. Thus Wallace's self-consciousness about cliché and reader response also necessarily applies to understated Joycean epiphany, for even epiphanic shock can become troublingly recursive in the "fashionable modern minimal exercise, going through its weary motions as it slouches toward epiphany" ("Westward" 359).

3. Wallace is particularly deft in choosing Lilith from Cheers for his narrator's undoing, as the name evokes Eve's powerful predecessor.

4. Ironically, as in all of the interviews in Brief Interviews with Hideous Men, readers are not permitted to hear the interviewer's questions, only the interviewee's response, so the interviewer is already silenced on the level of discourse while the law student attempts to silence her on the level of story.

5. To write about Wallace representing suicide as communication is necessarily to raise the issue of his own suicide. What it may or may not have communicated to those who cared about Wallace is a topic that has merited and will continue to merit its own discussion. Here I only note that Wallace's suicide also shifted emphasis from Wallace as speaker to his readers, readers who are forced "to imagine what all must have happened."

6. I am grateful to one of the anonymous readers of this article for pointing out another instance in which heart and center are indeed conflated. In the 2009 film, Agora, the astronomer Hypatia rationalizes her belief in a center of the universe by saying that if there isn't a center, it would break her heart.

7. More recently, reviewing Consider David Foster Wallace, Burn writes, "There's little doubt that Wallace exhibited a remarkable and voracious intellect, but a 
near-deification has allowed him to define the terms of his own critical reception too completely" (467).

8. Similarly, Harris argues that, "Having it 'both ways,'Wallace attempts in his fiction to recuperate what he calls 'single-entendre principles' ... while at the same time employing defamiliarizing techniques associated with postmodernism to remind his readers that not only the book they are reading but, in certain fundamental ways, the world they inhabit are made out of language" (173). Indeed, Harris makes explicit what has perhaps remained implicit in my reading: Wallace never lets readers forget that the naive emotions (signifieds) that they believe they discover in Wallace's texts are finally signifier effects.

\section{Works cited}

Agora. Dir. Alejandro Amenábar. Perf. Rachel Weisz. Focus Features, 2009. Film. Bauerle, Ruth. "Date Rape, Mate Rape: A Liturgical Interpretation of 'The Dead." New Alliances in Joyce Studies. Ed. Bonnie Kime Scott. Newark: U of Delaware P, 1988. 113-25.

Boswell, Marshall. Understanding David Foster Wallace. Columbia: U of South Carolina P, 2003.

Burn, Stephen J. “Consider David Foster Wallace.” Rev. of Consider David Foster Wallace, by David Hering. Modernism/modernity 18.2 (2011): 465-68. David Foster Wallace's Infinite Jest: A Reader's Guide. New York: Continuum, 2003.

Cheng,Vincent J. Joyce, Race, and Empire. Cambridge: Cambridge UP, 1995.

Cioffi, Frank Louis. “'An Anguish Become Thing': Narrative as Performance in David Foster Wallace's Infinite Jest." Narrative 8.2 (2000): 161-81.

Freud, Sigmund. Civilization and Its Discontents. Trans. James Strachey. New York: Norton, 1961.

Giles, Paul. "Sentimental Posthumanism: David Foster Wallace." Twentieth-Century Literature 53.3 (2007): 327-44.

Goerlandt, Iannis." "Put the Book Down and Slowly Walk Away': Irony and David Foster Wallace's Infinite Jest." Critique: Studies in Contemporary Fiction 47.3 (2006): 309-28.

Harris, Charles B. "David Foster Wallace: 'That Distinctive Singular Stamp of Himself." Critique: Studies in Contemporary Fiction 51.2 (2010): 168-76.

Holland, Mary K. “'The Art's Heart's Purpose': Braving the Narcissistic Loop of David Foster Wallace's Infinite Jest." Critique: Studies in Contemporary Fiction 47.3 (2006): 218-42.

Jacobs, Timothy. “The Brothers Incandenza:Translating Ideology in Fyodor Dostoevsky's The Brothers Karamazov and David Foster Wallace's Infinite Jest." Texas Studies in Literature and Language 49.3 (2007): 265-92. 
Joyce, James. “The Dead.” Dubliners. Ed. Margot Norris. New York: Norton, 2006.

—. A Portrait of the Artist as a Young Man. Ed. John Paul Riquelme. New York: Norton, 2007.

—. Ulysses. Ed. Hans Walter Gabler, et al. New York: Random House, 1986.

McLaughlin, Robert L. "Post-Postmodern Discontent: Contemporary Fiction and the Social World." Symploke 12.1-2 (2004): 53-68.

Nichols, Catherine. "Dialogizing Postmodern Carnival: David Foster Wallace's Infinite Jest." Critique: Studies in Contemporary Fiction 43.1 (2001):3-16.

Norris, Margot. Joyce's Web: The Social Unraveling of Modernism. Austin: U of Texas P, 1992.

Pynchon, Thomas. The Crying of Lot 49. New York: Perennial Classics, 1999.

Rother, James. "Reading and Riding the Post-Scientific Wave:The Shorter Fiction of David Foster Wallace." Review of Contemporary Fiction 13.2 (1993): 216-34.

Sedgwick, Eve Kosofsky. Between Men: English Literature and Male Homosocial Desire. New York: Columbia UP, 1985.

van Ewijk, Petrus. "I' and the 'Other': The Relevance of Wittgenstein, Buber and Levinas for an Understanding of AA's Recovery Program in David Foster Wallace's Infinite Jest." English Text Construction 2.1 (2009): 132-45.

Wallace, David Foster. Brief Interviews with Hideous Men. New York: Little, Brown, 1999.

—. "Certainly the End of Something or Other, One Would Sort of Have to Think (Re John Updike's Toward the End of Time)." Consider the Lobster and Other Essays. New York: Little, Brown, 2006. 51-59.

_. "E Unibus Pluram:Television and US Fiction." A Supposedly Fun Thing I'll Never Do Again. New York: Little, Brown, 1997. 21-82.

__. "Good Old Neon.” Oblivion. New York: Little, Brown, 2004. 141-81. . "Here and There." Girl with Curious Hair. New York: Norton, 1989. 149-72.

-. Infinite Jest. New York: Little, Brown, 1996.

-. The Pale King. New York: Little, Brown, 2011.

."Westward the Course of Empire Takes Its Way." Girl with Curious Hair New York: Norton, 1989. 231-373.

Woolf,Virginia. Mrs. Dalloway. Ed. Bonnie Kime Scott. Orlando: Harcourt, 2005. 
Copyright of Twentieth Century Literature is the property of Twentieth Century Literature and its content may not be copied or emailed to multiple sites or posted to a listserv without the copyright holder's express written permission. However, users may print, download, or email articles for individual use. 